\title{
Article/Artigo
}

\section{Clinical and laboratory alterations in dogs naturally infected by Leishmania chagasi}

\author{
Alterações clínicas e laboratoriais em cães naturalmente infectados por Leishmania chagasi
}

\author{
José Cláudio Carneiro de Freitass ${ }^{1}$, Diana Célia Sousa Nunes-Pinheiro ${ }^{1}$, Belarmino Eugênio Lopes Neto ${ }^{1}$, \\ Glauco Jonas Lemos Santos ${ }^{1}$, Cyntia Rafaelle Amaral de Abreu ${ }^{1}$, Roberta Rocha Braga ${ }^{2}$, Rafael de Morais Campos ${ }^{3}$ \\ and Ligene Fernandes de Oliveira ${ }^{4}$
}

\begin{abstract}
Introduction: Canine visceral leishmaniasis (CVL) is a zoonotic disease with different clinical manifestations. Parasitism often occurs in bone marrow, but changes have been observed in peripheral blood and serum biochemical parameters. The aim of this study was to evaluate the hematological and biochemical parameters in dogs naturally infected by Leishmania chagasi. Methods: Eighty-five adult dogs of both sexes and various weights and ages from the Zoonosis Control Center of Fortaleza (CCZ) were used, selected by immunofluorescence assay (IFA) and considered positive with IFA titers greater than 1:40 and by visualizing amastigotes of Leishmania chagasi in smears obtained by bone marrow aspiration. The dogs $(\mathrm{n}=85)$ were grouped according to clinical signs: negative $(\mathrm{CN}=7)$, subclinical $(\mathrm{CS}=10)$, and clinical $(\mathrm{CC}=68)$. Blood samples were collected for determination of hematological and biochemical serum values. The experimental protocol was approved by the CEUA/UECE. Results: The most frequent clinical signs were cachexia (77.9\%), keratitis (61.8\%), and lymphadenopathy $(55.9 \%)$, and $86.8 \%$ of the animals showed more than one clinical sign characteristic of CVL. In CC were observed reductions in red blood cells (63\%), hematocrit (72\%), and hemoglobin $(62 \%)$, as well as leukocytosis $(33 \%)$, neutropenia $(28 \%)$, thrombocytopenia $(50 \%)$, uremia $(45 \%)$, hyperproteinemia $(53 \%, \mathrm{p}<0.05)$, hypergammaglobulinemia $(62 \%$, $\mathrm{p}<0.01$ ), and hypoalbuminemia (58\%). Conclusions: Animals with the clinical form of the disease demonstrate hematological and biochemical changes consistent with anemia, uremia, hyperproteinemia, and hyperglobulinemia, which present themselves as strong clinical markers of visceral leishmaniasis associated with the signs previously reported.
\end{abstract}

Keywords: Dogs. Canine visceral leishmanisis. Biomarkers. Anemia. Uremia. Hyperglobulinemia.

\section{RESUMO}

Introdução: Aleishmaniose visceral canina (LVC) é uma zoonose com diferentes manifestações clínicas. O parasitismo ocorre frequentemente na medula óssea e têm sido relatadas alterações hematológicas e bioquímicas. Objetivou-se avaliar os parâmetros clínicos, hematológicos e bioquímicos de cães naturalmente infectados por Leishmania chagasi. Métodos: Utilizaram-se 85 cães adultos, ambos os sexos, peso e idade variados, oriundos do Centro de Controle de Zoonoses de Fortaleza, selecionados pela reação de imunofluorescência indireta (RIFI), sendo considerados positivos os animais com títulos de RIFI $\geq 1: 40$ e pelo exame parasitológico das formas amastigotas de Leishmania chagasi em esfregaços de medula óssea. Os cães foram agrupados conforme os sinais clínicos associados à doença: negativos $(\mathrm{CN}=7)$; subclínicos $(\mathrm{CS}=10)$ e clínicos $(\mathrm{CC}=68)$. Amostras de sangue foram coletadas para determinação dos parâmetros hematológicos e bioquímicos séricos. O protocolo experimental foi aprovado pelo CEUA/UECE, protocolo n ${ }^{\circ}$ 08622833-1. Resultados: Os sinais clínicos mais frequentes foram caquexia $(77,9 \%)$, ceratoconjuntivite $(61,8 \%)$ e linfadenopatia $(55,9 \%)$, sendo que $86,8 \%$ dos animais apresentaram mais de um sinal clínico característico de LVC. Em CC foram observadas reduções nas hemácias (63\%), hematócrito (72\%) e hemoglobina (62\%), leucocitose (33\%), neutropenia (28\%), trombocitopenia (50\%), uremia (45\%), hiperproteinemia $(53 \%, \mathrm{p}<0,05)$, hiperglobulinemia $(62 \%, \mathrm{p}<0,01)$ e hipoalbuminemia $(58 \%)$. Conclusões: Concluiu-se que os animais com a forma clínica da doença apresentam alterações condizentes com anemia, uremia, hiperproteinemia e hiperglobulinemia, as quais se apresentam como marcadores clínicos da leishmaniose visceral, associados aos sinais previamente relatados.

Palavras-chaves: Cães. Leishmaniose visceral canina. Biomarcadores. Anemia. Uremia. Hiperglobulinemia.

1. Programa de Pós-Graduação em Ciências Veterinárias, Faculdade de Veterinária, Universidade Estadual do Ceará, Fortaleza, CE. 2. Núcleo Regional de Ofiologia, Universidade Federal do Ceará, Fortaleza, CE. 3. Laboratório de Fisiofarmacologia Cardio-Renal, Instituto Superior de Ciências Biomédicas, Universidade Estadual do Ceará, Fortaleza, CE. 4. Centro de Controle de Zoonoses de Fortaleza, Fortaleza, CE.

Address to: Dr. José Claudio Carneiro de Freitas. Programa de Pós-Graduação em Ciências Veterinárias/ FAVET/UECE. Av. Paranjana 1700, Campus do Itaperi, Serrinha, 60740-000 Fortaleza, CE, Brasil. Phone: 558531019840

e-mail: claudiofavet@bol.com.br

Received in 21/01/2011

Accepted in 29/09/2011

\section{INTRODUCTION}

Visceral leishmaniasis is a zoonosis that affects humans when they come into contact with the transmission cycle of the parasite ${ }^{1}$. It is one of the most relevant emerging diseases worldwide, and Brazil is among the countries of Latin America that present the greatest number of human cases, about $90 \%$ of annual cases ${ }^{2}$.

Although humans can also act as reservoirs of the agent and play a role in the transmission cycle, the dog is considered one of the most important links in the epidemiological chain of leishmaniasis ${ }^{3}$. Canine visceral leishmaniasis (CVL) is transmitted through the bite of insects known as sandflies, mainly the species Lutzomyia longipalpis and L. cruzi, which convey the infective promastigotes. The main agent of visceral leishmaniasis in Brazil is Leishmania (Leishmania) chagasi ${ }^{1,4}$.

The pathogenesis of CVL involves several factors, and a decisive factor in the disease progression is associated with the immune response that the animal develops against the parasite ${ }^{5-7}$. In this case, the antibodies, rather than having a protective function, become highly harmful, participating in inflammatory processes and being responsible for most of the clinical signs associated with $\mathrm{CVL}^{6,8,9}$.

The infection may present itself in clinical form (clinical dogs), in which dogs show clinical signs and/or typical clinical and laboratory changes with confirmation of Leishmania chagasi, or in subclinical form (subclinical dogs), in which dogs show no clinical and laboratory changes, but the presence of Leishmania chagasi is confirmed by routine diagnostic tests ${ }^{10}$.

The hematological and serum biochemical parameters, although limited in the diagnosis of $\mathrm{CVL}$, are very useful in evaluating the clinical status of the animal and the extent of lesions and might give indications on the animal prognosis ${ }^{11,12}$. However, there is little information on these parameters and on biomarkers of leishmaniasis.

Considering the relevance of the disease and the scarcity of information about the clinical parameters 
and biomarkers of CVL, we carried out this study to evaluate the hematological and biochemical aspects of dogs naturally infected by Leishmania chagasi.

\section{METHODS}

\section{Animals}

Adult dogs $(\mathrm{n}=85)$, varying in age and weight and of no defined breeds, were used. The dogs were from the Zoonosis Control Center of Fortaleza (CCZ), collected through the program SOS Cão.

\section{Immunofluorescence assay for selection of animals}

Animals suspected of being infected by Leishmania chagasi were selected by the immunofluorescence assay (IFA) technique, with those having IFA titers greater than 1:40 considered seropositive.

The serological diagnosis of CVL was performed in the CCZ of Fortaleza using standardized kits supplied by Bio-Manguinhos. The principle of the test used consists of the reaction of sera eluted with antigens from Leishmania chagasi set on microscope slides. Subsequently, we used a fluorescent conjugate to elucidate the reaction, considering the sera that showed fluorescence as reactive and the sera that showed no fluorescence as nonreactive. These were used as positive and negative reference controls, respectively.

\section{Parasitological diagnosis}

With the animal anesthetized, a puncture was made in the bone marrow to obtain smears, which were placed on microscope slides set in methanol and stained with fast dye using the principle of eosin. The smears were observed under an optical microscope under immersion oil (1,000x magnification), and samples that showed the presence of amastigotes of Leishmania chagasi in bone marrow were considered positive.

\section{Experimental groups}

All dogs were examined by observing the typical clinical signs of CVL, such as onychogryphosis, apathy, keratoconjunctivitis, hepatosplenomegaly, cachexia, lymphadenopathy, skin ulcers, fever, alopecia, mucosal ulceration, peeling, eczema, vomiting, and rectal bleeding and edema formation.

The dogs were divided into three groups according to SolanoGallego et al..$^{10}$ : negative dogs $(\mathrm{ND}=7)$, which did not show clinical and laboratory alterations (hematology and biochemistry) and were negative for leishmaniasis by serology and parasitology; subclinical dogs $(S D=10)$, which did not show clinical and laboratory alterations but were positive for Leishmania chagasi infection; and clinical dogs $(\mathrm{CC}=68)$, which showed clinical and laboratory alterations in routine testing and had infection confirmed by serological and parasitological diagnosis.

\section{Collection of blood samples}

Blood $(10 \mathrm{~mL})$ was collected from dogs in the different groups by jugular venipuncture with a sterile syringe; $5 \mathrm{ml}$ of blood was placed into a tube containing anticoagulant EDTA (ethylenediamine tetraacetic acid) for hematological evaluation, and another $5 \mathrm{~mL}$ into a tube containing separation gel, without anticoagulant, for serum biochemistry evaluation. Sera were obtained by centrifugation, aliquoted, and stored at $-20^{\circ} \mathrm{C}$ until biochemical analysis.

\section{Hematological assessment}

The blood samples in EDTA were mixed and subjected to an automated blood analyzer (Cell Dyn 3600) for complete blood count. The hematological parameters evaluated were white blood cells (in $\times 10^{3} / \mathrm{dL}$ ), including total leukocytes (TL) and differential leukocytes, neutrophils (Neu), eosinophils (Eos), monocytes (Mon), basophils (Bas), and lymphocytes (Lym); red blood cells; erythrocytes (RBC, in $\left.\times 10^{6} / \mathrm{dL}\right)$; hemoglobin $(\mathrm{Hb}$, in $\mathrm{g} / \mathrm{dL})$; hematocrit (Ht, in \%); and total platelets (Plt, in $\times 10^{3} / \mathrm{mm}^{3}$ ). The results of the blood tests were compared to the reference values for canine species according to Meyer et al. ${ }^{13}$.

\section{Biochemical evaluation}

In the serum samples from dogs, the levels of urea (U, in $\mathrm{mg} / \mathrm{dL}$ ), creatinine (Crea, in $\mathrm{mg} / \mathrm{dL}$ ), total protein (TP, in $\mathrm{g} / \mathrm{dL}$ ), albumin (Alb, in $\mathrm{g} / \mathrm{dL}$ ), and globulin (Glob, in $\mathrm{g} / \mathrm{dL}$ ); and the enzyme activity of glutamic oxaloacetic transaminase (GOT, in U/L) and glutamic pyruvic transaminase (GPT, in $\mathrm{U} / \mathrm{L}$ ) were determined. For total protein, the albumin/globulin $(\mathrm{A} / \mathrm{G})$ ratio was used. The serum dosage was determined by an automated system (Konelab $60 \mathrm{i}$ ) using specific commercial kits (Wiener Lab®), according to the manufacturer's methodology.

The biochemical evaluation results obtained were compared to the reference values for canine species according to Kaneko et al. ${ }^{14}$.

\section{Statistical analysis}

The results were expressed as means and standard deviations. For comparison between groups, an analysis of variance (ANOVA) for parametric data was performed. Tukey's test was used to determine differences between groups $(\mathrm{p}<0.05)$. The results on the $\mathrm{A} / \mathrm{G}$ ratio were compared between groups using the Kruskal-Wallis test and Dunn's test $(\mathrm{p}<0.05)$.

\section{Ethical considerations}

The experimental protocol was approved by the Ethics Committee for Animal Use of the State University of Ceará (CEUA/ UECE), protocol SPU 08622833-1.

\section{RESULTS}

\section{Clinical signs of dogs positive for Leishmania chagasi}

The results of the evaluation of typical clinical signs of CVL were expressed in percentages (\%) and are shown in Table 1. The more frequent clinical signs were cachexia $(77.9 \%)$, keratoconjunctivitis (61.8\%), and lymphadenopathy (55.9\%), and $86.8 \%$ of the animals showed more than one typical clinical sign of CVL.

\section{Hematological changes in dogs positive for Leishmania chagasi}

The results of the evaluation of red blood cells from animals in groups ND, SD, and CD are presented in Table 2. There was a reduction in the mean values of erythrocyte $\left(4.88 \times 10^{6} / \mathrm{mL}\right)$, hematocrit $(31.87 \%)$, and hemoglobin $(10.84 \mathrm{~g} / \mathrm{dL})$ in group CD compared to the reference values for dogs. There was no significant difference between groups. It was observed that among the animals belonging to the $\mathrm{CD}$ group, $63 \%$ had reduced erythrocyte counts (below $5.5 \times 10^{6} / \mu \mathrm{L}$ ), $72 \%$ had decreased hematocrit levels (below $37 \%$ ), and $62 \%$ presented a decrease in hemoglobin (below $12 \mathrm{~g} / \mathrm{dL}$ ). There were no significant changes in red blood cells in group SD. 
TABLE 1 - Clinical signs observed in dogs in group CD (clinical dogs) naturally infected by Leishmania chagasi, from the Zoonosis Control Center in Fortaleza, Ceará, Brazil.

\begin{tabular}{lrr}
\hline Clinical sign & Number & Percentage \\
\hline Onychogryphosis & 23 & 33.8 \\
\hline Hepatosplenomegaly & 31 & 45.6 \\
\hline Cachexia & 53 & 77.9 \\
\hline Lymphadenopathy & 38 & 55.9 \\
\hline Keratoconjunctivitis & 42 & 61.8 \\
\hline Injuries by ectoparasites & 35 & 51.5 \\
\hline Skin ulcers & 24 & 35.3 \\
\hline Fever & 22 & 32.4 \\
\hline Apathy & 19 & 27.9 \\
\hline Alopecia & 21 & 30.9 \\
\hline Mucosal ulceration & 8 & 11.8 \\
\hline Peeling and eczema & 22 & 32.4 \\
\hline Vomiting & 6 & 8.8 \\
\hline Rectal bleeding & 5 & 7.4 \\
\hline Edemaciation & 23 & 33.8 \\
\hline More than one clinical sign & 59 & 86.8 \\
\hline & & \\
\hline
\end{tabular}

TABLE 2 - Hematology and platelet parameters in dogs with clinical and subclinical infections, naturally infected by Leishmania chagasi.

\begin{tabular}{|c|c|c|c|c|}
\hline Parameter & Reference $^{13}$ & Mean \pm SD & Median & Range \\
\hline & \multicolumn{3}{|c|}{ Negative dogs $(n=7)$} & \\
\hline $\mathrm{RBC} \times 10^{6} / \mu \mathrm{L}$ & $5.5-8.5$ & $5.66 \pm 0.49$ & 5.58 & $5.04-6.33$ \\
\hline $\mathrm{Hb} \mathrm{g} / \mathrm{dL}$ & $12-18$ & $12.24 \pm 1.33$ & 12.7 & $10.3-13.7$ \\
\hline Ht \% & $37-55$ & $37.23 \pm 3.76$ & 38.7 & $31.7-41.1$ \\
\hline MCV fL & $60-77$ & $65.56 \pm 2.47$ & 66.1 & $62.9-69.4$ \\
\hline $\mathrm{MCH}$ pg & $19.3-24.3$ & $21.46 \pm 0.84$ & 21.6 & 20.2-22.9 \\
\hline MCHC \% & $32-36$ & $32.74 \pm 0.75$ & 32.8 & 31.8-34.1 \\
\hline RDW \% & - & $17.4 \pm 1.03$ & 17.2 & 16.4-19.4 \\
\hline \multirow[t]{2}{*}{ Plt $\times 10^{3} / \mathrm{mm}^{3}$} & $175-500$ & $169.61 \pm 22.73$ & 176.5 & $124-189.5$ \\
\hline & \multicolumn{3}{|c|}{ Subclinical dogs $(n=10)$} & \\
\hline $\mathrm{RBC} \times 10^{6} / \mu \mathrm{L}$ & $5.5-8.5$ & $5.71 \pm 1.64$ & 6.03 & $1.74-7.4$ \\
\hline $\mathrm{Hb} \mathrm{g} / \mathrm{dL}$ & $12-18$ & $13.24 \pm 3.84$ & 13.7 & $4.2-17.5$ \\
\hline Ht \% & $37-55$ & $38.88 \pm 11.14$ & 39.75 & $12.4-50.8$ \\
\hline MCV fL & $60-77$ & $67.84 \pm 4.4$ & 67.7 & $61.4-76.3$ \\
\hline $\mathrm{MCH}$ pg & $19.3-24.3$ & $23.25 \pm 1.26$ & 23.2 & 21.4-25.1 \\
\hline MCHC \% & $32-36$ & $34.04 \pm 0.93$ & 33.85 & $32.8-35.6$ \\
\hline RDW \% & - & $15.53 \pm 1.54$ & 15.4 & 13.1-18.9 \\
\hline \multirow[t]{2}{*}{ Plt $\times 10^{3} / \mathrm{mm}^{3}$} & $175-500$ & $226.8 \pm 99.85$ & 257 & $65.7-330$ \\
\hline & \multicolumn{3}{|c|}{ Clinical dogs $(n=68)$} & \\
\hline $\mathrm{RBC} \times 10^{6} / \mu \mathrm{L}$ & $5.5-8.5$ & $4.88 \pm 1.64$ & 4.61 & $1.57-7.93$ \\
\hline $\mathrm{Hb} \mathrm{g} / \mathrm{dL}$ & $12-18$ & $10.84 \pm 3.91$ & 10.05 & $3.78-19.7$ \\
\hline Ht \% & $37-55$ & $31.87 \pm 10.7$ & 29.85 & $11.3-54.9$ \\
\hline MCV fL & $60-77$ & $66.14 \pm 5.66$ & 66.05 & $48.6-78.8$ \\
\hline $\mathrm{MCH}$ pg & $19.3-24.3$ & $22.16 \pm 2.2$ & 22.4 & $13.9-26$ \\
\hline MCHC \% & $32-36$ & $33.5 \pm 1.59$ & 33.7 & 28.6-38.9 \\
\hline RDW \% & - & $17.15 \pm 2.54$ & 16.9 & $12-28.1$ \\
\hline Plt $\times 10^{3} / \mathrm{mm}^{3}$ & $175-500$ & $223.3 \pm 159.4$ & 183 & $1.53-792$ \\
\hline
\end{tabular}

SD: standard deviation; RBC: red blood cells; Hb: hemoglobin; Ht: hematocrit; MCV: mean corpuscular volume; $\mathbf{M C H}$ : mean corpuscular hemoglobin; MCHC: mean corpuscular hemoglobin concentration; RDW: anisocytosis index; Plt: platelet.
The average platelet counts were within the normal limits among the groups (Table 2). However, 50\% of group CD showed a reduction in the number of platelets.

The results of the evaluation of white blood cells from animals in groups ND, SD, and CD are presented in Table 3. The CD and $\mathrm{SD}$ groups showed, on average, a mild lymphocytosis in relation to the reference values for the species. The average counts of total leukocytes, neutrophils, monocytes, eosinophils, and basophils in both groups showed no changes compared to the reference values. The groups did not differ statistically $(\mathrm{p}<0.05)$. However, among the animals belonging to the $\mathrm{CD}$ group, $33 \%$ had total leukocyte counts exceeding $17 \times 10^{3} / \mathrm{dL}$, and $28 \%$ had neutrophil counts greater than $11.5 \times 10^{3} / \mathrm{dL}$. Among the SD group animals, there were no changes observed in the parameters of the white blood cells.

TABLE 3 - Leukocyte parameters in dogs with clinical and subclinical infections, naturally infected by Leishmania chagasi.

\begin{tabular}{|c|c|c|c|c|}
\hline Parameter & Reference $^{13}$ & Mean \pm SD & Median & Range \\
\hline & \multicolumn{3}{|c|}{ Negative dogs $(n=7)$} & \\
\hline $\mathrm{TL} \times 10^{3} / \mathrm{mm}^{3}$ & $6-17$ & $9.78 \pm 3.75$ & 8.93 & $5.74-16.9$ \\
\hline Neu $\times 10^{3} / \mathrm{mm}^{3}$ & $3-11.5$ & $4.11 \pm 1.81$ & 3.96 & $2.14-7.68$ \\
\hline $\operatorname{Lym} \times 10^{3} / \mathrm{mm}^{3}$ & $1-4.8$ & $3.02 \pm 1.25$ & 3.11 & $1.31-4.56$ \\
\hline Mon $x 10^{3} / \mathrm{mm}^{3}$ & $0.1-1.3$ & $0.71 \pm 0.86$ & 0.035 & $0.02-1.8$ \\
\hline Eos $\times 10^{3} / \mathrm{mm}^{3}$ & $0.1-1.3$ & $0.27 \pm 0.35$ & 0.11 & $0-0.898$ \\
\hline \multirow[t]{2}{*}{ Bas $\times 10^{3} / \mathrm{mm}^{3}$} & Rare & $1.11 \pm 1.29$ & 0.53 & $0-3.45$ \\
\hline & \multicolumn{3}{|c|}{ Subclinical dogs $(n=10)$} & \\
\hline $\mathrm{TL} \times 10^{3} / \mathrm{mm}^{3}$ & $6-17$ & $11.67 \pm 3.79$ & 11.25 & $6.3-17$ \\
\hline Neu $\times 10^{3} / \mathrm{mm}^{3}$ & $3-11.5$ & $9.81 \pm 8.11$ & 7.82 & $1.26-43.7$ \\
\hline $\operatorname{Lym} \times 10^{3} / \mathrm{mm}^{3}$ & $1-4.8$ & $5.53 \pm 4.48$ & 3.04 & $1.47-13$ \\
\hline Mon $\times 10^{3} / \mathrm{mm}^{3}$ & $0.1-1.3$ & $0.56 \pm 0.52$ & 0.39 & $0.003-1.4$ \\
\hline $\operatorname{Eos} \times 10^{3} / \mathrm{mm}^{3}$ & $0.1-1.3$ & $0.16 \pm 0.19$ & 0.08 & $0-0.52$ \\
\hline \multirow[t]{2}{*}{ Bas $\times 10^{3} / \mathrm{mm}^{3}$} & Rare & $0.26 \pm 0.7$ & 0 & $0-2.24$ \\
\hline & \multicolumn{3}{|c|}{ Clinical dogs $(n=68)$} & \\
\hline $\mathrm{TL} \times 10^{3} / \mathrm{mm}^{3}$ & $6-17$ & $15.24 \pm 9.77$ & 12.9 & $2.5-52.9$ \\
\hline $\mathrm{Neu} \times 10^{3} / \mathrm{mm}^{3}$ & $3-11.5$ & $5.42 \pm 3.98$ & 5.07 & $1.03-13.6$ \\
\hline $\operatorname{Lym} \times 10^{3} / \mathrm{mm}^{3}$ & $1-4.8$ & $5.17 \pm 5.62$ & 3.2 & $0.65-31.6$ \\
\hline Mon $\times 10^{3} / \mathrm{mm}^{3}$ & $0.1-1.3$ & $0.65 \pm 0.87$ & 0.27 & $0.005-4.27$ \\
\hline Eos $\times 10^{3} / \mathrm{mm}^{3}$ & $0.1-1.3$ & $0.24 \pm 0.41$ & 0.04 & $0-1.8$ \\
\hline Bas $\times 10^{3} / \mathrm{mm}^{3}$ & Rare & $0.23 \pm 1.22$ & 0 & $0-9.86$ \\
\hline
\end{tabular}

SD: standard deviation; TL: total leukocytes; Neu: neutrophils; Lym: lymphocytes; Mon: monocytes; Eos: eosinophils; Bas: basophils.

\section{Biochemical changes in serum of dogs seropositive for Leishmania chagasi}

The average levels of GOT and GPT in animals from different groups are shown in Table 4. In all the groups, the activity of transaminases was within the normal range for dogs (GOT: 23 to $66 \mathrm{IU}, \mathrm{GPT}: 23$ to $66 \mathrm{IU})$, and there were no significant differences between groups $(\mathrm{p}<0.05)$.

The levels of urea and creatinine are presented in Table 4. It can be observed that the $\mathrm{CD}$ group showed an average serum urea level $(65.12 \mathrm{mg} / \mathrm{dL}$ ) above the reference value for the species ( 21 to $60 \mathrm{mg} /$ $\mathrm{dL})$. This change was observed in $45 \%$ of the animals. The average concentration of creatinine was within the reference values ( 0.5 to $1.5 \mathrm{mg} / \mathrm{dL}$ ) in all groups, although $17 \%$ of group CD presented higher levels. There were no significant changes between groups $(\mathrm{p}<0.05)$. 
TABLE 4 - Biochemical parameters in dogs with clinical and subclinical infections, naturally infected by Leishmania chagasi.

\begin{tabular}{|c|c|c|c|c|}
\hline Parameter & Reference $^{13}$ & Mean \pm SD & Median & Range \\
\hline & \multicolumn{3}{|c|}{ Negative dogs $(\mathbf{n}=7)$} & \\
\hline $\mathrm{U} \mathrm{mg} / \mathrm{dL}$ & $21-60$ & $33.43 \pm 9.47$ & 28 & $25-49$ \\
\hline Crea mg/dL & $0.5-1.5$ & $0.69 \pm 0.15$ & 0.7 & $0.5-0.9$ \\
\hline GPT U/L & $23-66$ & $40.14 \pm 14.95$ & 43 & $23-60$ \\
\hline GOT U/L & $23-66$ & $52.43 \pm 25.09$ & 48 & $25-94$ \\
\hline $\mathrm{TPg} / \mathrm{dL}$ & $5.4-7.1$ & $6.47 \pm 1.11$ & 6.4 & $5.3-8.2$ \\
\hline Alb g/dL & $2.6-3.3$ & $2.68 \pm 0.44$ & 2.65 & $2.6-3.3$ \\
\hline Glob g/dL & $2.7-4.4$ & $3.98 \pm 1.21$ & 3.55 & $2.8-5.5$ \\
\hline \multirow[t]{2}{*}{$\mathrm{A} / \mathrm{G}$} & $0.59-1.1$ & $0.73 \pm 0.26$ & 0.75 & $0.4-1.1$ \\
\hline & \multicolumn{3}{|c|}{ Subclinical dogs $(n=10)$} & \\
\hline $\mathrm{U} \mathrm{mg} / \mathrm{dL}$ & $21-60$ & $25.6 \pm 4.4$ & 24.5 & $21-33$ \\
\hline Crea mg/dL & $0.5-1.5$ & $0.78 \pm 0.19$ & 0.75 & $0.5-1.2$ \\
\hline GPT U/L & $23-66$ & $28 \pm 11.55$ & 24.5 & $21-60$ \\
\hline GOT U/L & $23-66$ & $37.9 \pm 11.95$ & 39.5 & $19-65$ \\
\hline $\mathrm{TPg} / \mathrm{dL}$ & $5.4-7.1$ & $6.54 \pm 0.54$ & 6.75 & $5.4-7.1$ \\
\hline $\mathrm{Alb} g / \mathrm{dL}$ & $2.6-3.3$ & $2.99 \pm 0.28$ & 3.05 & $2.6-3.3$ \\
\hline Glob g/dL & $2.7-4.4$ & $3.6 \pm 0.5$ & 3.65 & $2.8-4.4$ \\
\hline \multirow[t]{2}{*}{$\mathrm{A} / \mathrm{G}$} & $0.59-1.1$ & $0.86 \pm 0.13$ & 0.85 & $0.6-1.1$ \\
\hline & \multicolumn{3}{|c|}{ Clinical dogs $(n=68)$} & \\
\hline $\mathrm{U} \mathrm{mg} / \mathrm{dL}$ & $21-60$ & $65.12 \pm 60.78$ & 44 & $21-356$ \\
\hline Crea mg/dL & $0.5-1.5$ & $1.14 \pm 0.81$ & 0.9 & $0.4-5.1$ \\
\hline GPT U/L & $23-66$ & $59.38 \pm 144.74$ & 29.5 & $2-1107$ \\
\hline GOT U/L & $23-66$ & $59.67 \pm 50.71$ & 41.5 & $9-287$ \\
\hline $\mathrm{TPg} / \mathrm{dL}$ & $5.4-7.1$ & $7.36 \pm 1.12$ & 7.2 & $5.2-10.3$ \\
\hline Alb g/dL & $2.6-3.3$ & $2.54 \pm 0.76$ & 2.4 & $1.4-4.5$ \\
\hline Glob g/dL & $2.7-4.4$ & $4.81 \pm 1.26$ & 4.8 & $2.5-8$ \\
\hline $\mathrm{A} / \mathrm{G}$ & $0.59-1.1$ & $0.59 \pm 0.34$ & 0.5 & $0.3-1.7$ \\
\hline
\end{tabular}

SD: standard deviation; U: urea; Crea: creatinine; GPT: glutamic pyruvic transaminase; GOT: glutamic oxaloacetic transaminase; TP: total proteins; Alb: albumin; Glob: globulin; A/G: albumin-globulin ratio.
The average levels of total protein, globulin, albumin, and albumin/globulin (A/G) are shown in Table 4. The total protein was increased in the CD group $(7.36 \mathrm{~g} / \mathrm{dL})$ compared to the reference values $(5.4$ to $7.1 \mathrm{~g} / \mathrm{dL})$, and the change is significant for the ND and SD groups ( $<<0.05)$ (Table 5). In the CD group, 53\% of the animals showed elevated levels of total protein, which is associated with increased levels of globulin fractions $(4.81 \mathrm{~g} / \mathrm{dL})$ compared to the reference values $(2.7$ to $4.4 \mathrm{~g} / \mathrm{dL}$ ), while the albumin fraction $(2.54 \mathrm{~g} / \mathrm{dl})$ was low compared to the reference values for dogs ( 2.6 to $3.3 \mathrm{~g} / \mathrm{dL}$ ). There were significant differences in the levels of globulin in group CD compared to those in the ND and SD groups $(\mathrm{p}<0.01)$ (Table 5). Hyperglobulinemia was presented by $62 \%$ of group $C D$, while hypoalbuminemia was reported in $58 \%$ of the animals.

There were no changes in the $\mathrm{A} / \mathrm{G}$ ratio between the groups when compared to the reference values (0.59 to 1.11). Although the average $\mathrm{A} / \mathrm{G}$ ratios in the SD group showed significant changes compared to those in the ND and CD groups $(\mathrm{p}<0.05)$, the changes were not relevant since the values were within the normal limits.

\section{DISCUSSION}

Visceral leishmaniasis is a chronic infectious disease that can be characterized by the development of a symptomatic or asymptomatic infection accompanied by the appearance of various typical clinical signs ${ }^{1}$.

The high percentage of animals with typical clinical signs of leishmaniasis (Table 1) demonstrates that a clinical form of the disease may evolve with signs such as vomiting and cachexia and involve more than one clinical sign, as observed in this study $(86.8 \%$ of the animals). These data confirm the clinical findings that have been reported in the literature ${ }^{15,16}$. It is noteworthy that Mattos Jr et al. ${ }^{15}$ found $88.8 \%$ of animals with leishmaniasis presenting more than one clinical sign.

In this study we found alterations consistent with anemic conditions in animals belonging to group CD. Anemia in dogs naturally infected with Leishmania chagasi is one of the most common laboratory findings, as reported by Reis et al. ${ }^{12}$ in symptomatic dogs, and by Ciaramella and Corona ${ }^{6}$ in about $60 \%$ of infected animals, but the factors involved in its pathogenesis are complex and poorly known. The reason for anemia may be related to bleeding, hemolysis, inflammation, renal failure, chronic disease, and marrow aplasia or hypoplasia ${ }^{17}$. However, no correlation has been found between anemia and the appearance of clinical signs ${ }^{18}$.

The hematocrit and hemoglobin levels were below the reference values in the $\mathrm{CD}$ group; nevertheless, there were no significant changes found between the groups. Costa-Val et al. ${ }^{18}$ reported significant changes in hematocrit and hemoglobin in dogs with leishmaniasis regardless of the presence of multiple, few, or no typical signs of CVL in the animals.

Although the average platelet counts found in this study were within the normal range independent of the evaluated group, 50\% of the animals belonging to the $\mathrm{CD}$ group had thrombocytopenia. Some studies have reported thrombocytopenia as a typical sign of CVL ${ }^{19,20}$. Moreover, in a study by Costa-Val et al ${ }^{18}$ with 42 dogs positive for CVL, only $15 \%$ of the animals showed a decrease in the platelet counts.

With regard to the white blood cell count, there was no significant change in the studied groups. Leukocytosis (33\%) 
and neutropenia (28\%) were reported. Amusategui et al. ${ }^{21}$ reported that the leukocyte counts of symptomatic, oligosymptomatic, and asymptomatic dogs did not differ statistically among themselves, and there was no correlation between leukocyte count and clinical signs found in the studied groups. However, this study verified a trend towards increased levels of total leukocytes on the basis of clinical symptoms.

With respect to the lymphocyte count, there was a slight increase in the averages in the $\mathrm{SD}$ and $\mathrm{CD}$ groups compared to the reference values for dogs. Moreover, Paludo et al..$^{22}$ reported that the main alteration found in the white blood cell count of asymptomatic and symptomatic animals was a reduction in the average levels of lymphocytes.

The leishmaniases are a complex of diseases that involve immunological mechanisms, and as such, its worsening has been associated with increased antibody production. As a result of this production, formation of soluble and circulating immune complexes may occur; these complexes are deposited in organs and tissues, making them targets and leading to tissue damage ${ }^{23}$.

Assessment of liver function was performed in this study by measuring the plasma activity of transaminases. In general, there was no great activity observed for both GPT and GOT in all tested groups. And analyzing the data from this study, we found that only $11 \%$ of the animals belonging to the CD group had increased levels of GPT. CVL generally does not cause severe liver injuries ${ }^{6}$ because most liver lesions are due to the spread of infected macrophages, thus causing a chronic infection in this organ ${ }^{24}$. In this regard, these results do not corroborate the findings from studies done by Ciaramella et al..$^{25}$, which revealed a considerable increase in the concentration of GPT in animals with clinical symptoms.

In this study we observed an increase in the average levels of urea in group $\mathrm{CD}$, which could mean a probable renal compromise, although the average creatinine level in all groups was within the normal limits, according to the reference values for the species. It was found that only $17 \%$ of the animals belonging to the CD group presented creatinine levels above $1.5 \mathrm{mg} / \mathrm{dL}$, thereby demonstrating that the disease was still in the acute phase. These results are similar to those found by Abreu-Silva et al. ${ }^{26}$ which demonstrated that uremia is a major finding typical in dogs naturally infected by Leishmania chagasi. This uremia may have contributed to the anemia in the CD group, because urea, which has toxic effects on red blood cells, may decrease the half-life of erythrocytes ${ }^{18}$. Regarding renal function, it is important to determine the degree of injury and the prognosis of dogs with leishmaniasis by assessing the levels of creatinine and urea ${ }^{6}$. The renal damage may also be attributed to deposits associated with the specific IgM and IgG antibodies ${ }^{27}$.

In this work, the CD group had high average levels of total protein and globulin, and low levels of albumin. This increase may be associated with an increase in the levels of anti-Leishmania antibodies, related to the symptoms of the disease. The profile of proteins in plasma is considered one of the most reliable markers for monitoring CVL. The levels of total protein in serum are substantially increased in dogs with CVL and can reach levels above $10 \mathrm{~g} / \mathrm{dL}$, due mainly to high levels of $\beta$ - and $\gamma$-globulin ${ }^{6}$. Furthermore, it has been observed that both hyperproteinemia and hypergammaglobulinemia are the most common findings in dogs seropositive for Leishmania $s p p^{12,26}$. As CVL is a chronic disease that leads to an increase in the total protein concentration and its globulin fraction, a decrease in the albumin concentration can be observed as well ${ }^{6}$.
The animal infected with Leishmania spp can develop a cellular immune response mediated by Th 1 cells secreting IFN- $\gamma$ and TNF- $\alpha$, which are the predominant cytokines in asymptomatic dogs that show apparent resistance to visceral leishmaniasis. Moreover, there is evidence of a strong correlation between progression of the disease and the IL-4 and IL-10 from Th2 cells ${ }^{28}$. There are reports linking the development of symptoms of CVL with the increased amount of immunoglobulins ${ }^{24}$, indicating a direct correlation between high titers of IgG1 anti-Leishmania and the appearance of clinical signs, while IgG2 has been associated with asymptomatic $\operatorname{dog} s^{29}$.

It is noteworthy that $58 \%$ of group CD showed a reduction in the levels of serum albumin, which can be directly correlated with the edema formation observed in $33.8 \%$ of the animals. This has been observed in dogs with the appearance of clinical signs ${ }^{12}$ and can be explained by the migration of albumin into the extravascular regions, associated with fluid accumulation, with consequent edema formation ${ }^{30}$.

Therefore, it can be concluded that animals with the clinical form of the disease show hematological and biochemical changes consistent with anemia, uremia, hyperproteinemia, and hypergammaglobulinemia, which present themselves as strong markers for canine leishmaniasis associated with the signs previously reported.

\section{CONFLICT OF INTEREST}

The authors declare that there is no conflict of interest.

\section{FINANCIAL SUPPORT}

The first author has a scholarship provided by the Fundação Cearense de Apoio ao Desenvolvimento Científico e Tecnológico (FUNCAP).

\section{REFERENCES}

1. Brasil MS. Manual de Vigilância e Controle da Leishmaniose Visceral. $1^{\text {a }}$ ed. Brasília: Ministério da Saúde; 2006.

2. Monteiro EM, Silva JCF, Costa RT, Costa DC, Barata RA, Paula EV, et al. Leishmaniose visceral: estudo de flebotomíneos e infecção canina em Monte Claros, Minas Gerais. Rev Soc Bras Med Trop 2005; 38:147-152.

3. Ribeiro VM. Leishmaniose visceral canina: aspectos de tratamento e controle. Clín Vet 2007; 71:66-76.

4. Camargo-Neves VLF, Glasser CM, Cruz LL, Almeida RG. Manual de Vigilância e Controle da Leishmaniose Visceral Americana do Estado de São Paulo. $1^{\text {a }}$ ed. São Paulo: Secretaria de Estado da Saúde; 2006.

5. Ferrer L. Canine Leishmaniosis: Evalution of the immunocompromised patient. Wsava Congress Chooses 82002. [Acesso nov. 2010] Disponível em: http;//www. vin.com/proceedings/Proceedings.plx? CID=WSAVA2002\&PID=PR02653.

6. Ciaramella P, Corona M. Canine leishmaniasis: clinical and diagnostic aspects. VetLearn 2003; 25:358-368.

7. Miranda S, Martorell S, Costa M, Ferrer L, Ramis A. Characterization of circulating lymphocyte subpopulation in canine leishmaniasis throughout treatment with antimonials and allopurinol. Vet Parasitol 2007; 144:251-260.

8. Ciaramella P, Oliva G, De Luna L, Gradoni R, Ambrosio L, Cortese A, et al. A retrospective clinical study of canine leishmaniasis in 150 naturally infected by Leishmania infantum. Vet Rec 1997; 141:539-543.

9. Trotz-Williams L, Gradoni L. Disease risks for the travelling pet Leishmaniasis. In Practice 2003; 25:190-197.

10. Solano-Gallego L, Koutinas AF, Miró G, Cardoso L, Pennisi MG, Ferrer L, et al. Directions for the diagnosis, clinical staging, treatment end prevention of canine leishmaniosis. Vet Parasitol 2009; 14:1-18. 
11. Ikeda FA, Luvizotto MCR, Gonçalves ME, Feitosa MM, Ciarlini PC, Lima VMF. Perfil hematológico de cães naturalmente infectados por Leishmania chagasi no município de Araçatuba, São Paulo (Brasil): um estudo retrospectivo de 191 casos. Clín Vet 2003; 47:42-48.

12. Reis AB, Martins-Filho OA, Teixeira Carvalho A, Carvalho MG, Mayrink W, França-Silva JC et al. Parasite density and impaired biochemical/hematological status are associated with severe clinical aspects of canine visceral leishmaniasis. Res Vet Sci 2006; 81:68-75

13. Meyer DJ, Coles EH, Rich LJ. Medicina de Laboratório Veterinário - interpretação e diagnóstico. $1^{\text {a }}$ ed. São Paulo: Roca; 1995.

14. Kaneko JJ, Harvey JW, Bruss ML. Clinical biochemistry of domestic animals. $6^{\mathrm{a}}$ ed. San Diego: Academic Press; 2008.

15. Mattos Jr DG, Pinheiro JM, Menezes RC, Costa DA. Aspectos clínicos e de laboratório de cães soropositivos para leishmaniose. Arq Bras Med Vet Zootec 2004; 56:119-122.

16. Baneth G, Koutinas AF, Solano-Gallego L, Bourdeau P, Ferrer L. Canine leishmaniosis - new concepts and insights on an expanding zoonosis: part one. Trends Parasitol 2008; 24:324-330.

17. Koutinas AF, Polizopoulou ZS, Saridomichelakis MN, Argyriadis D, Fytianou A, Plevraki K. Clinical considerations on canine visceral leishmaniasis in Greece: a retrospective study of 158 cases (1989 - 1996). J Am Anim Hosp Assoc 1999; 35:376-383.

18. Costa-Val AP, Cavalcanti RR, Gontijo NF, Michalick MSM, Alexander B, Williams P, et al. Canine visceral leishmaniasis: Relationships between clinical status, humoral immune response, haematology and Lutzomyia (Lutzomyia) longipalpis infectivity. Vet J 2007; 174:636-643.

19. Soares MJV, Moraes JRE, Palmeira-Borges V, Miyazato LG, Moraes FR. Alterações renais em cães com leishmaniose visceral. J Ven Anim Toxins Includ Trop Dis 2005; 11:579-593.

20. Cortese L, Terrazzano G, Piantedosi D, Sica M, Prisco M, Ruggiero G, et al. Prevalence of anti-platelet antibodies in dogs naturally co-infected by Leishmania infantum and Erlichia canis. Vet J 2011; 188:118-121.

21. Amusategui I, Sainz A, Rodriguez F, Tesouro MA. Distribution and relationships between clinical and biopathological parameters in canine leishmaniasis. Eur J Epidemiol 2003; 18:147-156.

22. Paludo GR, Aquino LC, Lopes BCC, Silva PHC, Borges TS, Dias CA, Castro MB. Laboratorial findings of canine visceral leishmaniosis in Brasília, Brazil. Vet Clin Pathol 2007; 36:382-398.

23. Tizard IR. Imunologia Veterinária - Uma Introdução. 8a ed. Rio de Janeiro: Elsevier; 2009.

24. Silva FS. Patologia e patogênese da leishmaniose visceral canina. Rev Trop: Ci Agr Biol 2007; 1:20-31.

25. Ciaramella P, Pelagalli A, Cortese L, Pero ME, Corona M, Lombardi P, et al Altered platelet aggregation and coagulation disorders related to clinical findings in 30 dogs naturally infected by Leishmania infantum. Vet J 2005; 169: 465-467.

26. Abreu-Silva AL, Lima TB, Macedo AA, Moraes-Júnior FJ, Dias EL, Batista ZS, et al. Soroprevalência, aspectos clínicos e bioquímicos da infecção por Leishmania em cães naturalmente infectados e fauna de flebotomíneos em uma área endêmica na ilha de São Luís, Maranhão, Brasil. Rev Bras Parasitol Vet 2008; 17:197-203.

27. Soares MJV, Moraes JRE, Moraes FR. Renal involvement in canine leishmaniasis: a morphological and immunohistochemical study. Arq Bras Med Vet Zootec 2009; 61:785-790.

28. Barbiéri CL. Immunology of canine leishmaniasis. Parasite Immunol 2006; 28: 329-337.

29. Iniesta L, Gállego M, Portús M. Immunoglobulin G and E responses in various stages of canine leishmaniosis. Vet Immunol Immunopathol 2005; 103:77-81.

30. Kumar V, Abbas AK, Fausto N. Robins e Cotran: Patologia: Bases Patológicas das Doenças. $7^{\mathrm{a}}$ ed. São Paulo: Elsevier; 2005. 